\title{
Social and Cultural Dynamics in North Africa During the Holocene: An Introduction
}

\author{
Giulio Lucarini • Jörg Linstädter
}

Published online: 13 February 2021

(C) The Author(s), under exclusive licence to Springer Science+Business Media, LLC part of Springer Nature 2021

This special issue of the African Archaeological Review originated from the 22-1 Session organized by the 25th ACSPT-UISPP Commission (Art and Civilisations in the Sahara During Prehistoric Times - Union Internationale des Sciences Préhistoriques et Protohistoriques) at the 18th UISPP World Congress, held in the Université Paris 1 Panthéon-Sorbonne (June 4-9, 2018) (Fig. 1). The ACSPT-UISPP Commission, founded in 1991 by Gabriel Camps and Eduardo Ripoll Perelló, is currently chaired by Barbara E. Barich. The commission's primary aim is to advance knowledge about the ancient Saharan societies within their environmental contexts, from the Atlantic to the Red Sea. The commission provides an overview of the archaeological research carried out in this region and hosts meetings to circulate and exchange information on key issues such as Holocene climate and environment, cultural interactions, rock art, and the cognitive world.

The Paris session comprised of 19 presentations. It was one of the most comprehensive and best-attended

\footnotetext{
G. Lucarini $(\bowtie)$

Institute of Heritage Science (ISPC), National Research Council of Italy (CNR), Area della Ricerca di Roma 1, Montelibretti, Rome, Italy

e-mail: giulio.lucarini@cnr.it
}

\section{G. Lucarini}

Department of Asian, African and Mediterranean Studies, University of Naples L'Orientale, Naples, Italy

\section{G. Lucarini}

McDonald Institute for Archaeological Research, University of Cambridge, Cambridge, UK sessions at the 18th UISPP World Congress. In the framework of the general theme proposed for the congress, the session aimed to explore the economic, sociocultural, and technological responses to climate change in North Africa during the Holocene, and bring together specialists involved in innovative multidisciplinary projects. The session also encouraged a diachronic and multidisciplinary debate among scholars working in North African countries and using different research methodologies, especially for palaeoenvironmental and palaeoeconomic reconstruction, demographic modeling, analysis of material culture, and rock art studies.

The political instability of the past decade in most North African countries has affected archaeological research in the region. Foreign archaeologists, especially, have been pushed to rethink and reset their research agendas. Some have even shifted their interests towards more stable and safer regions. There were concerns that the instability would hold back previous research projects dedicated to the reconstruction of population

G. Lucarini

International Association for Mediterranean and Oriental Studies (ISMEO), Rome, Italy

J. Linstädter $(\bowtie)$

Deutsches Archäologisches Institut, Kommission für Archäologie Außereuropäischer Kulturen, Dürenstr. 35-37, 53173 Bonn,

Germany

e-mail: joerg.linstaedter@dainst.de 


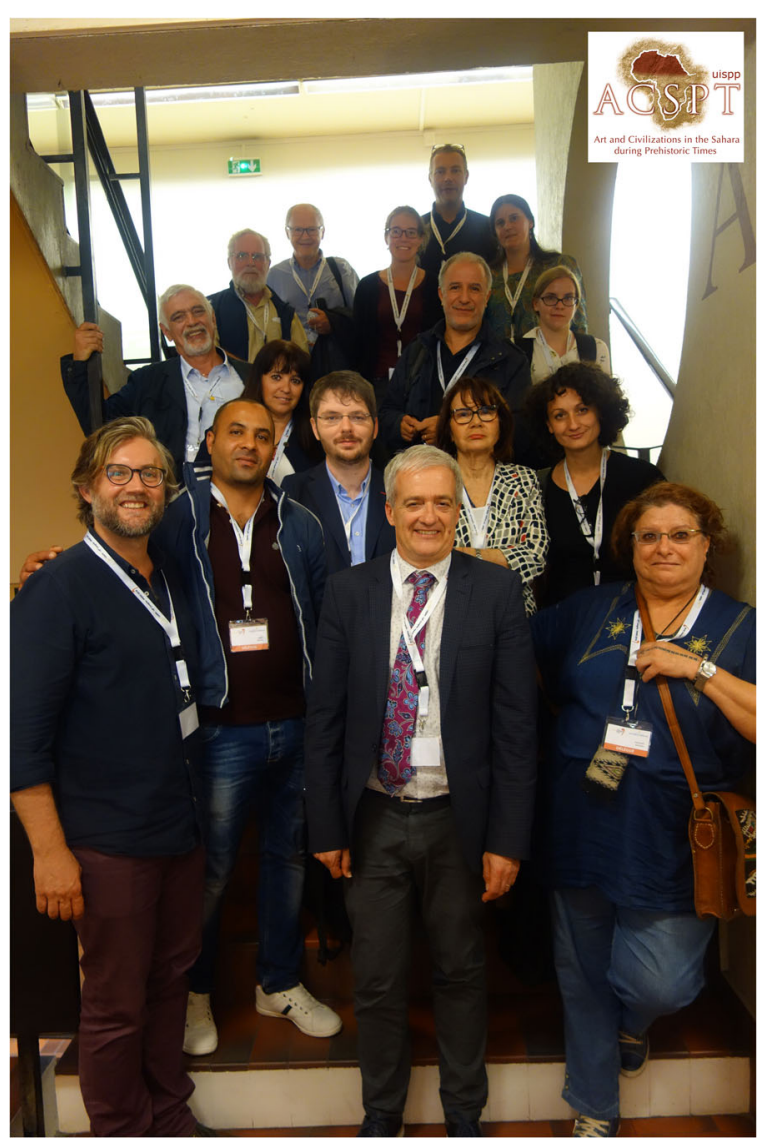

Fig. 1 Participants of the 22-1 session organized by the ACSPTUISPP Commission at the 18th UISPP World Congress in Paris (from left to right; top row: David Lubell, Graeme Barker, Alice Leplongeon, Jörg Linstädter, Katarina Kapustka; second row: Umberto Sansoni, Oriana Dal Bosco, Iddir Amara, Emily Tilby; third row: Ismail Saafi, Joshua Emmitt, Barbara E. Barich, Giacoma Petrullo; bottom row: Giulio Lucarini, Simon Holdaway, Malika Hachid)

patterns and sociocultural dynamics. However, many archaeologists have been able to work around these challenges through innovative fieldwork techniques, international collaboration, and multidisciplinary cutting-edge analytical works, thanks to the largescale, multiproxy, and multi-site projects that have been funded in recent years. These include the "Peopling the Green Sahara" and "MedAfrica" projects funded by the British Leverhulme Trust, the IRN-"DECAPAN" funded by the French CNRS, the "Neo-Innova" project funded by the Spanish MICINN, the "Eastern Rif Project, Morocco" of the University of Cologne and the German Archaeological Institute, and the Collaborative Research Center 608 funded by the German Research Foundation
(DFG). Archaeological science approaches, applied to freshly excavated materials and "cold cases" (Casanova et al. 2020; Dunne et al. 2012; Lucarini and Tomasso 2020; Perrin et al. 2020), and the spatial analysis of easily-accessible large datasets, such as the published radiocarbon dates from the Mediterranean African sites (Broodbank and Lucarini 2019; Lucarini et al. 2020), also added new insights. These studies have allowed a better re-evaluation of archaeological materials and samples from previous excavations stored in museums and laboratories. The session provided the opportunity to discuss these research strategies and methodological approaches and offered the participants the opportunity to examine several challenges and propose solutions. Circumstances such as a lack of laboratories for carrying out cutting-edge scientific analyses, as well as archaeological and environmental sample exportation bans imposed in some countries were also discussed during the session, as these must be taken into serious consideration when doing science-based archaeology in North Africa. In this sense, the application of specific approaches presented in some of the articles in this issue may help to address these issues.

This special issue includes seven articles that highlight the new research strategies, cutting-edge archaeometric approaches, and international collaborative efforts in the archaeology of North African Holocene. Most especially, this issue presents case studies in Mediterranean Africa and the Saharan region, and focus on how archaeological science is being used to answer behavioral, social, and cultural questions in the period from ca. 8500 to $1000 \mathrm{BC}$. The articles follow a geographical-chronological order. The first two cases relate to the Early and Middle Holocene Saharan region, and the following two focus on Western Maghreb. Two articles cover the Nile Delta, and the last piece in the special issue examines the implications of the radiocarbon database, MedAfriCarbon, for the cultural history of Mediterranean Africa, excluding Egypt.

In the first article, "The bone artifact collection from Wadi Ti-n-Torha (northern Tadrart Akakus, Libya): A reappraisal based on technological analysis," Giacoma Petrullo and Barbara E. Barich present a study of the bone tool industry excavated from the shelter sites of Tin-Torha Two Caves, Ti-n-Torha East, and Ti-n-Torha North, in the Libyan desert of the Tadrart Akakus during the 1970s. These sites were occupied from ca. 8500 BC 
to $4100 \mathrm{BC}$, first by hunter-gatherer groups and then by pastoralists. Technological analysis allowed the authors to identify trends in the selection of raw materials, animal species, and the methods and techniques used in the manufacture of the tools. The homogeneity of the styles of the bone tools across the sites and for over 3000 years is a testament to the long-term continuity of material culture traditions in the area.

"Searching for the right color palette: Source of pigments of the Holocene Wadi Sura paintings, Gilf Kebir, Western Desert (Egypt)," by Mohammed Hamdan and colleagues, uses geological, mineralogical, and geochemical analyses to propose the sources of the pigments used in the Wadi Sura rock art (southwestern Egypt). Colors used in the paintings include white, yellow, and several reddish hues, with rare black and greenish hues. The Raman spectroscopy and pXRF analyses of both raw coloring materials and archaeological pigments show that the ancient artists mainly used locally sourced inorganic clay-based pigments. Surprisingly, a lazurite content was also recognized among the raw materials, although this blue pigment does not seem to have been used in the Wadi Sura rock art panels. Lazurite is not well known in the geology of Egypt and has been detected for the first time in this study. The results indicate that access to the Silurian sandstones, mainly located on the plateau's northwestern slope, may have been one of the factors that influenced the selection of this area of the Gilf Kebir for rendering rock art images.

The article by Manuel Broich and colleagues, "The Early and Middle Holocene Lithic Industries of Ifri n'Etsedda (Eastern Rif, Morocco)," is a study of the lithic tools excavated between 2012 and 2014. Neolithic innovations such as pottery and domestic species appeared around $5600 \mathrm{BC}$ and were products of external influences. Conversely, the evidence suggests that lithic artifacts bear evidence of long-term local technological and behavioral traditions that continued from the hunting-gathering through the early agricultural phase. Ifri n'Etsedda provides evidence for two distinct Epipalaeolithic and late Early Neolithic (ENC) deposits. The authors argue that the lithic record of Ifri n'Etsedda does not indicate any significant change in terms of raw material supply, blank production, and tool distribution from the Early Epipalaeolithic to the Early Neolithic B. However, the Early Neolithic C lithic deposit shows changes in lithic technology. Therefore, a certain behavioral, and even population, continuity from the
Epipalaeolithic to the Early Neolithic period can be inferred from the sequence.

The article by Rainer Hutterer et al., entitled "Food and ornament: Use of shellfish at Ifri Oudadane, a Holocene settlement in NE Morocco," is part of the same Moroccan-German project in the Eastern Rif of Morocco as that of Broich et al. Recent excavations of the prehistoric rockshelter Ifri Oudadane yielded a rich marine and terrestrial fauna assemblage. The article presents an analysis of the shellfish from the 2011 trench, covering Epipaleolithic and Early Neolithic levels. Limpets (Patellidae), topshells (Trochidae), mussels (Mytilidae), and rock shells (Muricidae) formed $98 \%$ of the total mollusk fauna and were used as food remains; limpets prevailed in the Epipaleolithic and topshells in the Neolithic levels. There is evidence for a shift in the systematic butchering method of topshells (Phorcus turbinatus). The shells in Epipaleolithic levels were mostly smashed, while the topshells in Neolithic levels were usually topped. Analyses also showed the selection of specific taxa for different purposes: species used as food such as limpets, topshells, and mussels never show the indications of being used as ornament or tools, while the mollusks used as jewelry or tools were not part of the diet.

The article, "Kom W and X Basin: Erosion, deposition, and the potential for village occupation," by Joshua Emmitt and colleagues, revisits earlier investigations in the Fayum Oasis, Egypt. Twentieth-century excavations of stratified deposits at Kom W, adjacent to Lake Qarun, Fayum north shore, led to various interpretations. The prevalent one identifies the site as a Neolithic village, and this perspective has been influential in discussing the settlement pattern of Early to Middle Holocene Egypt. Recent studies of site formation processes cast doubts on these interpretations. From its initial formation, Kom W was subject to post-depositional processes, particularly wind erosion, which affected the site's current form and the preservation of features and artifacts within the deposits. The deflated deposits that surround Kom W suggest that the kom is not as unique as once imagined. In fact, the deposits are consistent with the other Early to Middle Holocene occupations in this region associated with domesticates but without the existence of villages.

The aim of the article, "The evolution of Lower Egyptian culture during the formative stages of the Egyptian state at Tell el-Iswid: The contribution of ceramic technology," by Jade Bajeot and Nathalie 
Buchez, is to investigate the crucial transitional period of the Egyptian state in the second half of the fourth millennium BC. The authors identify four ceramic technical traditions during this period at Tell el-Iswid, in the Nile Delta. By focusing on the evolution of these technical traditions over time, the study shows increasing contact between the Delta and the Middle/Upper Nile during Buto IIIa and the emergence of specialized ateliers in the Delta during Naqada IIIA2. The exogenous chaîne opératoire adopted in these workshops for manufacturing pottery shows that, in the beginning, the management of these ateliers was in the hands of potters coming from the south. Alongside this new production system, however, the local domestic tradition persisted. The technological approach to ceramic analysis adopted in this study is very promising. If implemented on a larger geographical scale, it may broaden our understanding of the social transformations during the Egyptian Predynastic period.

The final article, "New light on the silent millennia: Mediterranean Africa, ca. 4000-900 BC," by Giulio Lucarini and colleagues, focuses on a little-known period of North African history, between $4000 \mathrm{BC}$ and the onset of classical times. Why, except for the Nile Delta, is our archaeological knowledge of Mediterranean Africa during this period so limited? Can this information gap be attributed to aridification, or is it a product of bias in the archaeological research design? To answer these questions, this article uses data available on MedAfriCarbon, a spatially linked, publicly accessible database and web app comprising the ${ }^{14} \mathrm{C}$ dates from Mediterranean Africa, 12,000-600 BC, with details of associated cultural and economic information. Analysis of these data shows that most of Mediterranean Africa beyond the Nile was occupied to varying extents throughout the 3000 years covered in this article. With a few exceptions, the robust and resilient nature of local, mainly pastoral, ways of life militated against a shift towards a fully agricultural economy in the region.

The ACSPT-UISPP Commission has, in recent years, been deeply committed to advancing and disseminating knowledge about social and cultural dynamics and palaeoenvironmental studies of Holocene North Africa, especially through the organization of workshops and scientific meetings (Barich et al. 2005; Lucarini 2016). This special issue demonstrates the commission's holistic approach in terms of multidisciplinarity and its transregional focus. Although some regions of North Africa have become inaccessible, archaeologists have been creative in using new methodologies to analyze the artifact and environmental sample collections from previous excavations. The results of these studies are presented in this issue. They reinforce the compelling need for collaboration and interdisciplinary efforts across national boundaries.

Acknowledgments We would like to express our sincere thanks to all the colleagues who kindly reviewed the articles and provided helpful feedback. Special thanks go to Claire Malleson for the initial copyediting of this introduction. This special issue is dedicated to all the people who incessantly and tirelessly build intellectual bridges between North Africa and the rest of the World.

\section{References}

Barich, B. E., Tillet, T., \& Striedter, K. H. (eds.) (2005). Hunters vs. pastoralists in the Sahara: Material culture and symbolic aspects (Acts of the XIV UISPP Congress, Lieges, Sept. 2001; Symposium 51.1, Commission XXV). BAR International Series 1338. Oxford: Archaeopress.

Broodbank, C., \& Lucarini, G. (2019). The dynamics of Mediterranean Africa, ca. 9600-1000 BC: An interpretative synthesis of knowns and unknowns. Journal of Mediterranean Archaeology, 32(2), 195-267.

Casanova, E., Knowles, T. D. J., Bayliss, A., Dunne, J., Barański, M. Z., Denaire, A., et al. (2020). Accurate compoundspecific ${ }^{14} \mathrm{C}$ dating of archaeological pottery vessels. Nature, 580, 506-510.

Dunne, J., Evershed, R. P., Salque, M., Cramp, L., Bruni, S., Ryan, K., et al. (2012). First dairying in green Saharan Africa in the fifth millennium BC. Nature, 486, 390-394.

Lucarini, G. (2016). Editorial: The Neolithic from the Sahara to the Southern Mediterranean coast: A review of the most recent research. Quaternary International, 410, Part A, 2-5.

Lucarini, G., \& Tomasso, S. (2020). Editorial: Africa under the microscope: What's new in techno-functional analyses in archaeology? Quaternary International, 555, 1-5.

Lucarini, G., Wilkinson, T., Crema, E. R., Palombini, A., Bevan, A., \& Broodbank, C. (2020). The MedAfriCarbon Radiocarbon Database and Web Application: Archaeological dynamics in Mediterranean Africa, ca. 9600-700 BC. Journal of Open Archaeology Data, 8, 1. https://doi.org/10.5334/joad.60.

Perrin, T., Dachy, T., Gueret, C., Lubell, D., Chaid-Saoudi, Y., \& Green, W. (2020). Pressure knapping and the timing of innovation: New chrono-cultural data on prehistoric groups of the early Holocene in the Maghreb, northwest Africa. Radiocarbon, 62(2), 1-51.

Publisher's Note Springer Nature remains neutral with regard to jurisdictional claims in published maps and institutional affiliations. 